\title{
Referral Physicians' Knowledge of Radiation Dose: A Cross-sectional Study
}

\author{
Mohammad Rawashdeh ${ }^{1 *}$, Charbel Saade ${ }^{2}$, Ali Ibnian ${ }^{3}$, Ziad Bataineh ${ }^{1}$, Dana S. Al Mousa ${ }^{1}$, Patrick Brennan ${ }^{4}$, Feda Al-Tamimi $^{1}$, \\ Maryam Al-Husari ${ }^{5}$, Rula AbuTaimai ${ }^{6}$, Mark McEntee ${ }^{7}$ \\ ${ }^{1}$ Faculty of Applied Medical Sciences, Jordan University of Science and Technology, Irbid, Jordan; ${ }^{2}$ University of Canberra, \\ Canberra, Australia; ${ }^{3}$ King Abdullah University Hospital, Irbid, Jordan; ${ }^{4}$ Medical Image Optimisation and Perception Group, \\ Faculty of Health Sciences, The University of Sydney, Sydney, New South Wales, Australia; ${ }^{5}$ Department of Statistics, Faculty \\ of Science, Yarmouk University, ${ }^{6}$ Jordan Breast Cancer Program, Amman, Jordan; ${ }^{7}$ University College Cork, Discipline of \\ Diagnostic Radiography, Brookfield Health Sciences, Cork, Ireland
}

\section{Abstract}

Edited by: Sasho Stoleski Citation: Rawashdeh M, Saade C, Ibnian A, Bataineh Z Al Mousa DS, Brennan P, Al-Tamimi F, Al-Husari M, AbuTaimai R, McEntee M. Referral Physicians' Knowledge AbuTaimai R, McEntee M. Referral Physicians Knowledge
of Radiation Dose: A Cross-Sectional Study. Open Access https://doi.org/10.3889/oamims.2020.4727 Keywords: Radiation damage; Radiation dose; Radiation protection; Radiation risk Correspondence: Dr. Mohammad Rawashdeh, Faculty of Applied Medical Sciences, Jordan University of Science and Technology, Irbid, Jordan. E-mail: marawashdeh@just.edu.jo Received: 04-Apr-2020 Revised: $16-\mathrm{Oct}-2020$ Accepted: $19-O c t-2020$ Copyright: $\odot 2020$ Mohammad Rawashdeh Charbel Saade, Ali Ibnian, Ziad Bataineh, Dana S. Al Mousa, Patrick Brennan, Feda Al-Tamimi, Maryam Al-Husari, Rula AbuTaimai, Mark McEnte Jordan University of Sciences and Technology (grant no. $20190378)$
Competing Interests: The authors have declared that no competing interests exis. Open Access: This is an open-access article distributed under the terms of the Creative Commons AttributionNonCommercial 4.0 International License (CC BY-NC 4.0)
AIM: The purpose of the study was to evaluate the knowledge of referring physicians of general practitioners residents, and medical specialists in Jordan and the Middle East on radiation dose and its impact on vulnerable patients.

MATERIALS AND METHODS: The Institutional Review Board approved this study before data collection. A crosssectional study employed questionnaire that was distributed to respondents $(n=293)$ of general practitioners residents, specialists, and therapists. The questionnaire consisted of 29 questions. Nine questions concerned with demographics and the remaining 20 questions were divided into five sections: Radiation dose, ionizing radiation, pediatric radiation, pregnant women radiation, and radiation risks. The mean score was computed out of 20 . Chisquared test of independence was utilized to analyze each question. To compare the responses between the demographic variables groups, Kruskal-Wallis and Mann-Whitney tests were used.

RESULTS: Out of the 293 respondents, $128(43.7 \%)$ were aware of radiation. The average score of the questionnaire was 9.5 out of $20(47.5 \%)$. Within each section, the level of knowledge varied. Physicians had the highest level of knowledge in radiation risk ( $85.7 \%$ ) followed by ionizing radiation $(62.1 \%)$. The questionnaire revealed lower levels of knowledge in the areas of pediatric radiation, pregnant women radiation, and radiation dose. The percentages of respondents, (with fair to good level of knowledge), were $47.1 \%, 34.5 \%$, and $24.6 \%$, respectively.

CONCLUSION: The results of this study were consistent with previous studies that demonstrated a poor level of general knowledge in referring physicians regarding radiation dose, ionizing radiation, pediatric radiation, pregnant women radiation, and radiation risks.

\section{Introduction}

With the advent of imaging technology, ionizing radiation (IR) is considered one of the most valuable diagnostic tool in the detection and evaluation of disease and disorders [1]. Exposure of radiation workers and patients to IR is mainly evaluated on risk-benefit analysis [2]. Unnecessary exposure to IR should be avoided, as there is a dose-dependent increase in the risk of developing cancer [3]. The biological effects of IR are classified into either deterministic or stochastic effects [4], [5], [6]. Deterministic effects, which include cataracts or erythema, occur when IR exposure rises above a specific threshold dose. Certain cardiological interventional processes with multiple image acquisition and long screening times (e.g., radiofrequency ablation, percutaneous coronary intervention, etc.) increase the deterministic effects of IR exposure on patients and radiation workers [7]. On the other hand, the stochastic effect is considered a probabilistic event, as there is no recognized threshold dose. The probability of inducing the effect, but not the severity, will increase in relation to the dose and could be different between individuals. For example, a low dose of IR $<50 \mathrm{mSv}$ will not directly damage any organ in the body, but repeated exposures will increase cancer risk over the lifetime of the individual [8]. This risk can be mitigated by physicians ordering fewer unnecessary radiological examination procedures.

Both consultant and general physicians refer patients for radiological examinations and have a great responsibility to manage and moderate the IR dose patients will receive [9]. However, standardization and justification have emerged as a key concept in radiation protection and presents with challenges [10], [11]. Justification implies that the referring physician has determined the benefit toward the patient outweighs the risk of the radiation dose [12], however, both the medicolegal cloud and patient education have evolved over the last decade to which physicians are more inclined to request radiological examinations for patients to potentially prevent litigation. 
Studies have reported a lack of acceptable knowledge among physicians regarding exposure to radiation: In one survey, physicians underestimated the dose of radiation received in an arteriogram by 16-fold (ref). The remainder of the survey demonstrated physicians was delivering an average dose of IR six times greater than they estimated [13]. It is also reported that referring physicians have limited knowledge of ionizing radiation and the carcinogenic potential of such radiation, and that referral guidelines are not widely used [12], [13]. Poor knowledge regarding radiation doses and its impact among physicians and health professionals is a well-reported concern with limited comparisons in the middle east [3], [13], [14], [15], [16], [17], [18], [19], [20], [21], [22], [23], [24], [25], [26], [27]. Nevertheless, to the best of our knowledge, this is the first study to investigate the knowledge of referral physicians in Jordan and the Middle East on radiation dose and its impact on vulnerable patients.

\section{Methodology}

This prospective study obtained approval from the Institutional Review Board at 20190378. It was conducted in November 2018, consisting of an anonymous questionnaire applied and distributed online (Google survey) through social media networks to non-radiologist physicians with different specialties who are working in Jordanian hospitals.

\section{Population demographics}

The participants were asked to estimate their knowledge about radiation doses, ionizing radiation, radiation in a pediatric population, radiation in pregnant women, and radiation risks. Adequate sample size was met by convenience and snowball sampling. Using Cohen's formula (1992) [28], a power analysis showed that a sample of 293 would provide an $80 \%$ chance of detecting correlations of \pm 0.223 at $p \leq 0.05$.

\section{Questionnaire}

The questionnaire consisted of 29 mandatory questions; ninefordemographicinformation thatincluded gender, age, specialty, education (internship/resident/ consultant), year of graduation, specific formal courses about radiology in their curriculum, self-reporting for their knowledge about radiology, any history of previous courses on radiation doses and their risk, and the most frequent radiological examination routinely requested. The second part of the questionnaire consisted of 20 questions divided into five sections: Radiation dose, ionizing radiation, pediatric radiation, pregnant women radiation, and radiation risks. All the questions were in English with formats, including multiple-choice and open-ended true/false questions.

\section{Validation of the study tool}

The questions employed were consistent with the studies of [29], [30]. However, a few changes were made, which include adding and excluding some questions. To validate these changes, the updated questionnaire was presented to a panel of experienced radiographers, medical imaging residents, and an internal medicine physician who were not included in the study. Afterward, the study was again validated in a group of 10 physicians who assessed the questionnaire for clarity. These physicians were also excluded from the study results.

The reliability of the study tool was confirmed by the test-retest method, where the pilot study was resent with two weeks period on the same sample of (10) physicians.

\section{Data analysis}

Data from completed surveys were manually transferred to Excel (Microsoft, Redmond, WA, USA) then transferred to SPSS, version 20 (SPSS, Chicago, IL, USA) for statistical analysis. Before analysis, missing values and accuracy of data entry were checked by reviewing all variables. The mean score was computed out of 20 for all the sample questions. The Chi-squared test of independence was used to analyze each question for determining if there is a significant relationship between the answers. Kruskal-Wallis and MannWhitney tests were used for comparing the responses between the demographic variables groups. Numbers, percentage, maximum, minimum, $5^{\text {th }}$ percentile, mean, and $95^{\text {th }}$ percentile for the correct answers of the whole exam were calculated. The Khan et al. (2014) scale (30) for knowledge, attitude, and practice scores were adopted. In this scale, $\leq 50 \%$ was considered as having poor knowledge, $51-69 \%$ is considered a fair level of knowledge, while $70 \%$ and above demonstrates a good level of knowledge. The total statistical significance value was $p<0.05$.

\section{Results}

A total of 293 respondents completed the questionnaire, $51.5 \%$ were males and $94.2 \%$ were within 20-30 years of age. General practitioners were $48.1 \%$ of the respondents, residents made up $46.1 \%$, and the remainder was specialists (5.8\%). Approximately, onethird $(31.7 \%)$ of the respondents had previous courses on radiation doses of diagnostic imaging, and $73.7 \%$ 
had not had any specific courses in radiation doses. As for the self-reporting of knowledge about radiation dose, respondents had a scale of five levels to choose from. Respondents assessed their knowledge as "moderate" $48.5 \%$ of the time. Chest examination was the most frequently ordered examination by doctors (82.9\%), followed by ultrasound $(59.0 \%)$ and CT examinations $(55.3 \%)$. It was also noted that neither spine $(10.2 \%)$ nor MRI examinations (12.3\%) were as frequently ordered.

Less than half of the respondents $(43.7 \%)$ were able to answer at least half of the questions correctly. The average number of correct answers was 9.5 out of 20 , which indicates a general lack of knowledge (Table 1). The number of correct answers varied between sections. This questionnaire revealed that physicians knew the most regarding radiation risks, with the average of correctly answered questions instead (e.g., average of correctly answered questions of 184 [62.8\%]). The section on ionizing radiation had the second-highest rate of the correct answer, with an average of 172 (58.8\%). It was determined that the physicians possessed a low level of knowledge in the sections of pregnant women radiation, pediatric radiation, and radiation dose, with an average of correct answers of only 146 (49.7\%), 139 (47.6\%), and 96 (32.7\%). 47.1\%, 34.5\%, and $24.6 \%$ of respondents had form fair to a good level of knowledge in these sections.

Table 1: Descriptive analysis of correct answers of the whole exam

\begin{tabular}{ll}
\hline Measurements & $\mathrm{n}(\%)$ \\
\hline Maximum score & $18(90)$ \\
Minimum score & $3(15)$ \\
$5^{\text {th }}$ percentile & $4.00(20)$ \\
Mean of correct answers & $9.5(47.5)$ \\
$95^{\text {th }}$ percentile & $13.00(65)$ \\
\hline
\end{tabular}

Table 2 lists the number and percentage for the respondents' answers on the five sections of the questionnaire. Two hundred twenty-seven physicians $(77.5 \%)$ were able to correctly identify which examination produced the highest radiation dose. Fewer (58.3\%) were able to identify the examination with a prolonged period of radiation emission. Only $31.4 \%$ of the participants correctly answered the equivalent radiation dose from chest X-ray compared to an annual dose of background radiation. While $20.8 \%$ of the participants knew patients absorbed dose from a chest X-ray, only $4.1 \%$ knew the radiation dose the public receives from medical imaging. Although $4.1 \%$ were able to specify that the annual dose limit for patients in $\mathrm{mSv}$ is unlimited, $49.1 \%$ of the respondents answered with (I don't know). Within the ionizing radiation section, $66.2 \%$ of respondents were able to identify the examinations that ultrasound exam does not use ionizing radiation and $43.7 \%$ answered with MRI. Moreover, $43.7 \%$ of the respondents were aware of the acronym "ALARA".

Less than half of participants $(48.5 \%)$ were able to correctly identify the least radiosensitive organ, and $76.8 \%$ of them recognized that children are the
Table 2: Participants' answers to the five sections

\begin{tabular}{|c|c|c|}
\hline Questions & Answer & $\mathrm{n}(\%)$ \\
\hline \multicolumn{3}{|l|}{ Radiation dose (Questions 1-6) } \\
\hline \multirow{6}{*}{$\begin{array}{l}\text { Which of the following modalities is } \\
\text { responsible for most of radiation dose? }\end{array}$} & Ultrasound & $3(1.0)$ \\
\hline & Chest X-ray & $17(5.8)$ \\
\hline & СТ & $227(77.5)$ \\
\hline & MRI & $34(11.6)$ \\
\hline & Lumbar spine X-ray & $2(0.7)$ \\
\hline & I don't know & $10(3.4)$ \\
\hline Which of the following has a prolonged & PET-CT & $171(58.3)$ \\
\hline period of time of emitting radiation? & Abdomen CT & 40 (13.7) \\
\hline & Abdomen MRI & $29(9.9)$ \\
\hline & Barium study & $12(4.1)$ \\
\hline & I don't know & $41(14.0)$ \\
\hline How does the radiation dose from a chest & $1: 100$ & $92(31.4)$ \\
\hline X-ray compare to the annual dose of & $1: 10$ & $44(15.0)$ \\
\hline background radiation? & $1: 1$ & $9(3.1)$ \\
\hline & $10: 1$ & $27(9.2)$ \\
\hline & I don't know & $121(41.3)$ \\
\hline What is the patients absorbed dose from a & $0.02 \mathrm{mGy}$ & $61(20.8)$ \\
\hline chest X-ray? & $0.2 \mathrm{mGy}$ & $56(19.1)$ \\
\hline & $2 \mathrm{mGy}$ & $34(11.6)$ \\
\hline & i don't know & 142(48.5) \\
\hline How much radiation does the public receive & $1.5 \%$ & $40(13.6)$ \\
\hline from medical imaging? & $5 \%$ & $75(25.6)$ \\
\hline & $15 \%$ & $36(12.3)$ \\
\hline & $50 \%$ & $12(4.1)$ \\
\hline & I don't know & $130(44.4)$ \\
\hline What is the annual dose limit for patients & 10 & $46(15.7)$ \\
\hline in $\mathrm{mSv}$ ? & 20 & $63(21.5)$ \\
\hline & 50 & $28(9.6)$ \\
\hline & Unlimited & $12(4.1)$ \\
\hline & I don't know & $144(49.1)$ \\
\hline Ionizing radiation (Questions 7-10) & & \\
\hline Which of the following does not use ionizing & Ultrasound & $194(66.2)$ \\
\hline radiation? (Choose all that apply) & Chest X-ray & $26(8.9)$ \\
\hline & CT & $13(4.4)$ \\
\hline & MRI & $128(43.7)$ \\
\hline & Nuclear medicine & $30(10.2)$ \\
\hline & I don't know & $19(6.5)$ \\
\hline Do you know What does the acronym & Yes & $26(8.8)$ \\
\hline "ALARA" represent & No & $224(76.5)$ \\
\hline & I don't know & $43(14.7)$ \\
\hline Which one of the following is less sensitive & Thyroid & $11(3.7)$ \\
\hline to radiation & Breast tissue & $55(18.8)$ \\
\hline & Gonads & $43(14.7)$ \\
\hline & Kidney & $142(48.5)$ \\
\hline & I don't know & $42(14.3)$ \\
\hline Which one of the following is most sensitive & Children & $225(76.8)$ \\
\hline to radiation: & Adolescents & $15(5.1)$ \\
\hline & Adults & $13(4.4)$ \\
\hline & Elderly & $10(3.4)$ \\
\hline & I don't know & $30(10.2)$ \\
\hline Pediatric radiation (Questions 11-13) & & \\
\hline In pediatric population what are the most & Liver & $25(8.5)$ \\
\hline sensitive organs to radiation & Kidneys & $58(19.8)$ \\
\hline & Gonads & $148(50.5)$ \\
\hline & Stomach & $5(1.7)$ \\
\hline & I don't know & $57(19.5)$ \\
\hline Fetal tissue is susceptible to radiation, & Less than 20 weeks & $235(80.2)$ \\
\hline especially during: & Between 20 and 30 weeks & $19(6.5)$ \\
\hline & 30 weeks to term & $12(4.1)$ \\
\hline & I don't know & $27(9.2)$ \\
\hline Estimate the radiosensitivity of 5 -year-old & The same & $21(7.2)$ \\
\hline patient in comparison to an adult? & Less & $41(14.0)$ \\
\hline & 5 times more & $93(31.7)$ \\
\hline & 10 times more & 35 (11.9) \\
\hline & I don't know & $103(35.2)$ \\
\hline Pregnant women radiation (Questions 14-16) & & \\
\hline Can pregnant women be submitted to skull & Yes & $126(43.0)$ \\
\hline CT only? & No & $124(42.3)$ \\
\hline & I don't know & $43(14.7)$ \\
\hline Can pregnant women be submitted to or & Yes & $119(40.6)$ \\
\hline screening mammography? & No & 139 (47.5) \\
\hline & I don't know & 35 (11.9) \\
\hline Should every woman in childbearing age be & Yes & $181(61.8)$ \\
\hline submitted to a pregnancy test before being & No & $82(28.0)$ \\
\hline submitted to radiography of the pelvis & I don't know & $30(10.2)$ \\
\hline Radiation risks (Questions 17-20) & & \\
\hline Does the risk for developing cancer & Yes & $177(60.4)$ \\
\hline increase with the dose value and may be & No & $68(23.2)$ \\
\hline present even with a single exposure? & I don't know & $48(16.4)$ \\
\hline Should any activity involving radiation be & Yes & $210(71.7)$ \\
\hline justified in relation to available alternatives & No & $44(15.0)$ \\
\hline & I don't know & $39(13.3)$ \\
\hline Should all exposures to radiation & Yes & $165(56.3)$ \\
\hline be maintained as low as reasonably & No & $50(17.1)$ \\
\hline achievable (ALARA)? & I don't know & $78(26.6)$ \\
\hline Should physicians and technicians who & Yes & $256(87.3)$ \\
\hline perform procedures utilizing ionizing radiation & No & $26(8.9)$ \\
\hline always be protected with shielding equipment & I don't know & $11(3.8)$ \\
\hline $\begin{array}{l}\text { and keep themselves as far as possible from } \\
\text { the radiation source? }\end{array}$ & & \\
\hline
\end{tabular}


most sensitive age group to radiation. Similar results were observed in pediatric radiation section, where $50.5 \%$ of respondents knew the most sensitive organ to radiation in the pediatric population and only $11.9 \%$ of respondents correctly estimated the radiosensitivity of a 5-year-old child in comparison to an adult. However, most of the respondents $(80.2 \%)$ correctly identified the age when fetal tissue is most radiosensitive. In the pregnant women radiation section, $43.0 \%$ were aware that pregnant women can undergo a skull CT, 47.5\% knew pregnant women should not receive mammography, and $28.0 \%$ correctly reported that pregnancy testing is not mandatory for women of childbearing age before receiving a radiological examination of the pelvis.

Within radiation risks, the final section, $60.4 \%$ of the respondents correctly reported that the risk for developing cancer increases with dose, and there is a risk with a single exposure. Over half $(56.3 \%)$ of the respondents knew that all exposures to radiation should be maintained As Low As Reasonably Achievable (ALARA). Moreover, $71.7 \%$ of the respondents were aware that any activity involving radiation should be justified in relation to available alternatives and $87.3 \%$ of them answered correctly when they were asked if physicians and technicians who perform procedures utilizing ionizing radiation should always be protected with shielding equipment and keep themselves as far as possible from the radiation source.

Table 3 illustrates the inter-group differences in the average number of correct answers. When comparing scores by gender, the Kruskal-Wallis test showed statistically significant differences in the pediatric radiation $(p=0.044)$ and pregnant women radiation sections $(p=0.018)$, with male respondents scoring higher than female respondents. However, in the radiation risks section, females scored higher than males ( $p=0.009$ ). Statistically significant differences were also found in the radiation risks section when analyzing scores by age $(p=0.001)$, with those over 30 years of age scoring the highest. Education significantly influenced score in the ionizing radiation and radiation risks sections, with specialists scoring highest in both categories ( $p=0.045$ for both). Finally, specialty significantly influenced the pregnant women's radiation section scores $(p=0.017$ ) for both general surgery and specialty surgery. However, there were no statistically significant differences that are attributed to the variation in the year of graduation.

Most previous studies revealed an inadequate level of knowledge in radiation among physicians worldwide (Table 4). Radiation knowledge among doctors of all grades was described as lacking, poor, inadequate, unsatisfactory, and deficit.

\section{Discussion}

A poor level of radiation knowledge was found overall among the respondents of this study, despite their self-reported "moderate" knowledge. This inconsistency between the reported and actual level of knowledge could indicate that doctors are not aware of their deficiencies. These findings are consistent with previous studies in other countries [13], [25], [29], [31], [32], [33], which also revealed a low level of radiation knowledge among referring physicians. This study found that only $31.7 \%$ of the respondents had previous courses on radiation doses in diagnostic imaging which may be a contributing factor in the overall poor knowledge base. Bosanquet et al. [3] also indicated that the poor level of knowledge could be related to insufficient education at the undergraduate level. Another explanation for the results may be due to the fact that physicians are mainly trained on image diagnostics and interpretation, rather than radiation dose [23]. However, different findings were reported by Quinn et al. [34] where it was claimed there was no difference in knowledge between physicians who attended radiation safety courses, and those who did not.

Table 3: Knowledge score according to the physicians' characteristics

\begin{tabular}{|c|c|c|c|c|c|c|c|c|c|c|c|}
\hline \multirow[t]{2}{*}{ Variables } & \multirow[t]{2}{*}{$\mathrm{N}$} & \multicolumn{2}{|c|}{$\begin{array}{l}\text { Radiation Dose } \\
\text { (6 Questions) }\end{array}$} & \multicolumn{2}{|c|}{$\begin{array}{l}\text { Ionizing Radiation } \\
\text { (4 Questions) }\end{array}$} & \multicolumn{2}{|c|}{$\begin{array}{l}\text { Pediatric Radiation } \\
\text { (3 Questions) }\end{array}$} & \multicolumn{2}{|c|}{$\begin{array}{l}\text { Pregnant Women Radiation } \\
\text { (3 Questions) }\end{array}$} & \multicolumn{2}{|c|}{$\begin{array}{l}\text { Radiation risks } \\
\text { (4 Questions) }\end{array}$} \\
\hline & & Mean & $p$-value & Mean & $p$-value & Mean & $p$-value & Mean & $p$-value & Mean & $\mathrm{p}$-value \\
\hline \multicolumn{12}{|l|}{ Gender } \\
\hline Male & 151 & $32.5 \%$ & 0.766 & $46.5 \%$ & 0.228 & $50.0 \%$ & 0.044 & $41.0 \%$ & 0.018 & $64.5 \%$ & 0.009 \\
\hline Female & 142 & $33.0 \%$ & & $43.5 \%$ & & $44.3 \%$ & & $33.0 \%$ & & $73.5 \%$ & \\
\hline \multicolumn{12}{|l|}{ Age } \\
\hline $20-25$ years & 147 & $32.8 \%$ & 0.664 & $43.2 \%$ & 0.373 & $46.0 \%$ & 0.303 & $34.0 \%$ & 0.187 & $72.2 \%$ & 0.001 \\
\hline $25-30$ years & 124 & $32.3 \%$ & & $46.0 \%$ & & $47.0 \%$ & & $39.3 \%$ & & $62.5 \%$ & \\
\hline$>30$ years & 22 & $34.8 \%$ & & $47.5 \%$ & & $56.0 \%$ & & $45.3 \%$ & & $80.0 \%$ & \\
\hline \multicolumn{12}{|l|}{ Education } \\
\hline Internship & 141 & $32.8 \%$ & 0.895 & $44.0 \%$ & 0.045 & $45.3 \%$ & 0.192 & $33.0 \%$ & 0.077 & $71.2 \%$ & 0.045 \\
\hline Resident & 135 & $32.6 \%$ & & $44.2 \%$ & & $56.6 \%$ & & $40.0 \%$ & & $65.0 \%$ & \\
\hline Specialist & 17 & $33.3 \%$ & & $58.7 \%$ & & $56.6 \%$ & & $49.0 \%$ & & $77.7 \%$ & \\
\hline \multicolumn{12}{|l|}{ Specialty } \\
\hline Internal medicine & 75 & $34.1 \%$ & 0.303 & $45.2 \%$ & 0.336 & $48.0 \%$ & 0.508 & $39.3 \%$ & 0.017 & $69.2 \%$ & 0.435 \\
\hline Emergency doctors & 24 & $27.6 \%$ & & $40.5 \%$ & & $48.3 \%$ & & $30.3 \%$ & & $62.5 \%$ & \\
\hline General surgery & 31 & $32.6 \%$ & & $51.5 \%$ & & $54.6 \%$ & & $48.3 \%$ & & $63.5 \%$ & \\
\hline Special surgeries & 23 & $31.0 \%$ & & $48.7 \%$ & & $46.3 \%$ & & $47.6 \%$ & & $86.2 \%$ & \\
\hline \multicolumn{12}{|l|}{ Year of graduation } \\
\hline$<1$ year & 116 & $31.0 \%$ & 0.163 & $41.7 \%$ & 0.172 & $45.0 \%$ & 0.149 & $33.3 \%$ & 0.105 & $69.5 \%$ & 0.086 \\
\hline $1-2$ years & 53 & $34.8 \%$ & & $45.0 \%$ & & $44.0 \%$ & & $35.6 \%$ & & $69.2 \%$ & \\
\hline$>2$ years & 124 & $32.8 \%$ & & $48.7 \%$ & & $53.0 \%$ & & $43.0 \%$ & & $67.7 \%$ & \\
\hline
\end{tabular}


Table 4: Comparison between the samples and results of the health professionals' knowledge about radiation studies in Jordan and other countries

\begin{tabular}{|c|c|c|c|c|}
\hline Country & Reference & Year & Sample & Level of knowledge \\
\hline \multirow[t]{3}{*}{ Australia } & (16) & 2010 & Doctors in the emergency departments & Poor \\
\hline & (17) & 2010 & Student and intern & Lack of knowledge \\
\hline & (3) & 2011 & Doctors from all grades & Poor \\
\hline \multirow[t]{2}{*}{ Hong Kong } & (21) & 2012 & Local physicians, radiologists, and interns & Unsatisfactory \\
\hline & (22) & 2012 & Radiologists and non-radiologists doctors & $\begin{array}{l}\text { Inadequate among radiologists, and } \\
\text { particularly poor in non-radiologists }\end{array}$ \\
\hline India & (26) & 2014 & Physicians and junior residents & Deficit of knowledge \\
\hline Italy & (31) & 2017 & Physicians & Good level \\
\hline Jordan (This Study) & & 2018 & Internal medicine, emergency doctors, surgery internship, and minor surgeries & Poor \\
\hline Malaysia & (25) & 2012 & Specialists, house officers, medical officers, trainee lecturers. & Poor \\
\hline Morocco & (32) & 2017 & Medical specialists, surgeons, general practitioners, and residents & Poor \\
\hline Nigeria & (24) & 2012 & Medical doctors apart from radiologists & Poor \\
\hline Northern Ireland & (15) & 2008 & Consultants and junior doctors from a range of specialties & Poor \\
\hline Norway & (23) & 2010 & General practitioners & Poor \\
\hline Turkey & (14) & 2007 & Doctors and intern doctors & Inadequate \\
\hline \multirow[t]{4}{*}{ United Kingdom } & (13) & 2003 & Senior house officers, specialist registrars, consultants, and consultant radiologists & Poor \\
\hline & (19) & 2006 & $\begin{array}{l}\text { Radiologists, nuclear physicians, dual-accredited radiologist-nuclear medicine physicians, } \\
\text { medical physicists, and pulmonologists. }\end{array}$ & Lack of knowledge \\
\hline & (18) & 2017 & Senior medical students & Poor \\
\hline & $(20)$ & 2002 & Doctors of all grades, including consultant radiologists & Lack of knowledge \\
\hline
\end{tabular}

Despite the overall poor knowledge that was measured in this study, the respondents showed a fair knowledge about radiation risks $(69.0 \%)$, which was higher than levels reported by other studies [9], [32], [35]. Furthermore, $77.5 \%$ of the respondents in this study had a good level of knowledge about the modalities for radiation dose, in the contrary to the studies of Keijzers and Britton [16] and Gervais et al. [36], which showed that the mean error of the physicians' estimates of the radiation dose of imaging modalities was high.

Alternatively, participants showed a poor level of knowledge about radiation doses $(32.7 \%)$. This may be attributed to the precision of the questions; radiation specialists should be able to answer such questions, while the knowledge of physician is expected to be general. Unlike previous studies [13], [25], [29], [32], this study revealed a poor level of knowledge among physicians about ionizing radiation.

Other statistically significant differences were found between the age groups in the favor of the older age group (over 30 years of age) regarding the radiation risks section. This could be due to gaining experience with time. Bohl et al. [37] indicated that experienced physicians have greater knowledge regarding radiation and its effects. Furthermore, the results of this study revealed that specialists were significantly more knowledgeable in regards to ionizing radiation and radiation risks. When comparing the Jordanian case with cases from other countries, similarly, poor levels of knowledge were found [13], [17], [18], [25], [29], [32]. However, there were important differences in the demographics of the population, as some sampled students $(17,18)$ and some specialists [13], [25], [38].

Underestimation of the risk of radiation doses could expose patients to unnecessary radiological exams and increased risk of adverse events. Physicians must be made aware of the risks involved in receiving radiological examination [22]. Interventional training and courses on the effects of radiation exposure are recommended for physicians who regularly refer patients for such testing. Continuing medical education, quality controls, adherence to referral guidelines, and public campaigns can play a significant role in the quest for appropriate imaging for patients and dose reduction, in terms of collective and individual dose.

The limitations of this study include online distribution of the questionnaire that may lead to untrusted answers and possibility of selection bias. Moreover, the use of a self-reported questionnaire makes it difficult to validate the real knowledge about radiation dose of physicians.

\section{Conclusion}

The results of this study were consistent with previous studies that showed a general poor level of knowledge about radiation dose among referral physicians. This poor knowledge was attributed to the lack of educational courses about radiation. The highest level of knowledge was on radiation risk, followed by ionizing radiation, pediatric radiation, pregnant women radiation, and radiation dose. The poor level of knowledge argues the need for effective tools to expand radiation education for doctors.

\section{References}

1. Meric M, Bor D, Büget N, Oezkili M. The use of monte carlo technique for the determination of tissue-air ratios (TAR) in diagnostic energy rate. Phys Med. 1998;14(1):3-8.

2. Peloquin JM, PardiDS, SandbornWJ, Fletcher JG, McCollough CH, Schueler BA, et al. Diagnostic ionizing radiation exposure in a population-based cohort of patients with inflammatory bowel disease. Am J Gastroenterol. 2008;103(8):2015-22.

PMid:18564113

3. Bosanquet DC, Green G, Bosanquet AJ, Galland RB Gower-Thomas K, Lewis MH. Doctors' knowledge of radiation a two-centre study and historical comparison. Clin Radiol. 2011;66(8):748-51. https://doi.org/10.1016/j.crad.2011.03.009 


\section{PMid:21546010}

4. National Radiological Protection Board. Documents of the National Radiological Protection Board 7. London, UK: National Radiological Protection Board; 1996.

5. Hall EJ. Hyperthermia. In: Radiobiology for the Radiologist. Pennsylvania, United States: Lippincott Wilkins and Williams; 2000. p. 495-520.

6. International Commission on Radiological Protection. Recommendations on the Protection of Man and the Environment against lonising Radiation. Ontario, Canada: International Commission on Radiological Protection; 2008. Available from: http://www.icrp.org.

7. Vano E, Gonzalez L, Guibelalde E, Aviles P, Fernandez JM, Prieto $\mathrm{C}$, et al. Evaluation of risk of deterministic effects in fluoroscopically guided procedures. Radiat Prot Dosimetry. 2005;117(1-3):190-4. https://doi.org/10.1093/rpd/nci714 PMid: 16461530

8. Foffa I, Cresci M, Andreassi MG. Health risk and biological effects of cardiac ionising imaging: From epidemiology to genes. Int J Environ Res Public Health. 2009;6(6):1882-93. https://doi. org/10.3390/ijerph6061882

\section{PMid:19578466}

9. Jacob K, Vivian G, Steel J. X-ray dose training: Are we exposed to enough? Clin Radiol. 2004;59(10):928-34. https://doi. org/10.1016/j.crad.2004.04.020 PMid: 15451354

10. ICRP. The 2007 Recommendations of the international commission on radiological protection. ICRP publication 103. Ann ICRP. 2007;37(2-4):1-332. PMid: 18082557

11. ICRP. Radiation protection in medicine. ICRP publication 103. Ann ICRP. 2007;37(6):1-64. https://doi.org/10.1016/j. icrp.2008.07.001

12. Borgen L, Stranden E, Espeland A. Clinicians' justification of imaging: Do radiation issues play a role? Insights Imaging. 2010;1(3):193-200. https://doi.org/10.1007/s13244-010-0029-4 PMid:22347915

13. Shiralkar S, Rennie A, Snow M, Galland RB, Lewis $M H$, Gower-Thomas K. Doctors' knowledge of radiation exposure: Questionnaire study. BMJ. 2003;327(7411):371-2. https://doi. org/10.1136/bmj.327.7411.371

PMid:12919987

14. Arslanoglu A, Bilgin S, Kubali Z, Ceyhan MN, İlhan MN Maral I. Doctors' and intern doctors' knowledge about patients' ionizing radiation exposure doses during common radiological examinations. Diagn Interv Radiol. 2007;13(2):53-5. PMid:17562506

15. Soye J, Paterson A. A survey of awareness of radiation dose among health professionals in Northern Ireland. $\mathrm{Br} \mathrm{J}$ Radiol. 2008;81(969):725-9. https://doi.org/10.1259/bjr/94101717 PMid:18591196

16. Keijzers GB, Britton CJ. Doctors' knowledge of patient radiation exposure from diagnostic imaging requested in the emergency department. Med J Aust. 2010;193(8):450-3. https://doi. org/10.5694/j.1326-5377.2010.tb03998.x PMid:20955121

17. Zhou G, Wong D, Nguyen L, Mendelson R. Student and intern awareness of ionising radiation exposure from common diagnostic imaging procedures. J Med Imaging Radiat Oncol. 2010;54(1):17-23. https://doi. org/10.1111/j.1754-9485.2010.02132.x PMid:20377710

18. Scali E, Mayo J, Nicolaou S, Kozoriz M, Chang S. Senior medical students' awareness of radiation risks from common diagnostic imaging examinations. Can Med Educ J. 2017;8(4):e31-41. https://doi.org/10.36834/cmej.36874

PMid:29354195

19. Groves AM, Yates SJ, Win T, Kayani I, Gallagher FA, Syed R, et al. CT pulmonary angiography versus ventilation-perfusion scintigraphy in pregnancy: Implications from a UK survey of doctors' knowledge of radiation exposure. Radiology. 2006;240(3):765-70. https://doi.org/10.1148/radiol.2403050910 PMid: 16926327

20. Gower-Thomas K, Lewis M, Shiralkar S, Snow M, Galland R, Rennie A. Doctors' knowledge of radiation exposures is deficient. BMJ. 2002;324(7342):919. https://doi.org/10.1136/ bmj.324.7342.919/a

PMid: 11950757

21. Wong $\mathrm{CH}$, Huang B, Sin HK, Wong WL, Yiu KL, Ching TC. A questionnaire study assessing local physicians, radiologists and interns' knowledge and practice pertaining to radiation exposure related to radiological imaging. Eur J Radiol. 2012;81(3):e264-8. https://doi.org/10.1016/j.ejrad.2011.02.022

PMid:21439746

22. Lee RK, Chu WC, Graham CA, Rainer TH, Ahuja AT. Knowledge of radiation exposure in common radiological investigations: A comparison between radiologists and non-radiologists. Emerg Med J. 2012;29(4):306-8. https://doi.org/10.1136/ emermed-2011-200481

PMid:21873321

23. Kada S. A study of general practitioners' knowledge of ionizing radiation from diagnostic imaging examinations. Qual Prim Care. 2010;18(6):391-7.

PMid:21294981

24. Ahidjo A, Garba I, Mustapha Z, Abubakar A, Usman U. Referring doctors knowledge about radiation doses in patients undergoing common radiological examinations. J Med Med Sci. 2012;3(4):222-25.

25. Kew TY, Zahiah M, Zulkifli SZ, Noraidatulakma A, Hatta S. Doctor's knowledge regarding radiation dose and its associated risks: Cross-sectional stusy in a tertiary hospital in Malesial. Hong Kong J Radiol. 2012;15:71-9.

26. Gour S, Maurya RK, Singh PP, Sharma H, Maravi P. Evaluation of physicians and junior residents' knowledge and awareness of radiation dose and its risks: A cross-sectional survey in tertiary health centre of central India. Int J Res Med Sci. 2017;6(1):99105. https://doi.org/10.18203/2320-6012.ijrms20175502

27. Hayes A, Alspaugh JM, Bartelt D, Campion MB, Eng J, Gayler BW, et al. Radiation safety for the speech-language pathologist. Dysphagia. 2009;24(3):274-9. https://doi. org/10.1007/s00455-008-9201-0 PMid:19198942

28. Cohen J. A power primer. Psychol Bull. 1992;112(1):155-9. https://doi.org/10.1037/0033-2909.112.1.155 PMid:19565683

29. Madrigano RR, Abrão KC, Puchnick A, Regacini R. Evaluation of non-radiologist physicians' knowledge on aspects related to ionizing radiation in imaging. Radiol Bras. 2014;47(4):210-6. PMid:25741087

30. Selmi M, Natarajan M. Radiation awareness amongst junior doctors. J Adv Radiol Med Image. 2016;1(2):205. https://doi. org/10.15744/2456-5504.1.205

31. Khan $Y H$, Sarriff $A$, Khan AH, Mallhi TH. Knowledge, attitude and practice (KAP) survey of osteoporosis among students of a tertiary institution in Malaysia. Trop $\mathrm{J}$ Pharm Res. 2014;13(1):155-62. https://doi.org/10.4314/tjpr.v13i1.22

32. Campanella F, Rossi L, Giroletti E, Micheletti P, Buzzi F, Villani S. Are physicians aware enough of patient radiation protection? Results from a survey among physicians of Pavia district-Italy. 
BMC Health Serv Res. 2017;17(1):406. https://doi.org/10.1186/ s12913-017-2358-1

PMid:28615014

33. Semghouli S, Amaoui B, El Kharras A, Shaim A, Hakam OK Choukri A. Physicians knowledge of radiation risk in prescribing CT imaging in Moroccan hospitals. Br J Appl Sci Technol. 2017;20(3):1-8. https://doi.org/10.9734/bjast/2017/32491

34. Applegate K, Kang J. Speech-language pathologists' radiation knowledge and practices during completion of the modified barium swallow study: A survey. J Med Speech Lang Pathol. 2014;21(4):369-91. https://doi.org/10.1044/1058-0360(2003/054)

35. Quinn A, Taylor C, Sabharwal T, Sikdar T. Radiation protection awareness in non-radiologists. Br J Radiol. 1997;70(829):102-6. https://doi.org/10.1259/bjr.70.829.9059306

PMid:9059306

36. Rice HE, Frush DP, Harker MJ, Farmer D, Waldhausen JH,
APSA Education Committee. Peer assessment of pediatric surgeons for potential risks of radiation exposure from computed tomography scans. J Pediatr Surg. 2007;42(7):1157-64. https:// doi.org/10.1016/j.jpedsurg.2007.02.007

PMid: 17618874

37. Gervais N, Véronique G, Jacques J, Dominique V. How aware are Belgian permanent and resident emergency physicians of common medical costs and radiation doses? Eur J Emerg Med. 2011;18(6):344-50. https://doi.org/10.1097/ mej.0b013e3283466eea

PMid:21487298

38. Bohl DD, Hijji FY, Massel DH, Mayo BC, Long WW, Modi KD, et al. Patient knowledge regarding radiation exposure from spinal imaging. Spine J. 2017;17(3):305-12. https://doi. org/10.1016/j.spinee.2016.09.017

PMid:27664337 